AWEJ for Translation \& Literary Studies, Volume3, Number1. February 2019

DOI: http://dx.doi.org/10.24093/awejtls/vol3no1.18

Pp. 232-245

\title{
The Cuchulain Myth in the Poetry of W. B. Yeats
}

\author{
Fatima Zahra Touzani \\ Faculty of Letters and Human Sciences \\ Cadi Ayyad University, Marrakech, Morocco
}

\begin{abstract}
Much has been said about myth, especially in relation to poetry. Contemporary studies have also revealed modern poetry's immense interest in myth. However, only dispersed references to the potential impact the use of myth in poetry may have on nationalism have been made. Moreover, the complex interweaving of poetry and myth has been probed only in general terms, disregarding sundry aspects. Thus, this article investigates some issues pertaining to myth and poetry. Specifically, it interrogates the relationship between poetry and myth, both of which are cogently interwoven to the extent that we can hardly disassociate them. This interrogation attempts to question the role of the ubiquitous presence of myth in the poetry of William Butler Yeats. To meet this objective, this article explores the Cuchulain myth in his poems. It contends that Yeats uses this myth both as an artistic device that echoes the struggle of Irish nationalists and a means that enhances resistance.
\end{abstract}

Keywords: Cuchulain, functions of myth, Irish nationalism, modern poetry, Yeats

Cites as: Touzani, F. Z. (2019). George Bernard Shaw's Arms and the Man: A Stylistic Analysis. Arab World English Journal for Translation \& Literary Studies, 3 (1) 232-245. DOI: http://dx.doi.org/10.24093/awejtls/vol3no1.18 


\section{Introduction}

A myth may encapsulate many of the cardinal values or virtues that characterize a certain culture. While the Egyptian Sky God Ruler, Amon-Re, for example, epitomizes fertility, the Norse God, Balder, personifies light and purity. Similarly, Marduk the Babylonian, Zeus the Greek, Jupiter the Roman, Dagda the Celtic, Indra Vishnu Shiva the Indian, and many other mythical figures, permeated the past and may be ubiquitous in literature. This ubiquity stands for humans' need to understand an outwardly mysterious world. Though they appertain to different historical eras and various geographical settings, myths share a common search for understanding.

Despite its complexity, a myth is a simple and down-to-earth tool. It is a tool since it aims at understanding the mysteries that govern the world; since it attempts to appease the potential fear that may torment humans as tormented creatures doomed to suffer; since, most importantly, it conveys the general truths that characterize a particular culture. The use of myth may also stand for an unconscious human drive, or rather need, to explore the paranormal as a means to get rid of the bitter monotony of the normal.

Such tormenting worries, infinite questions, and incessant attempts have resulted in countless myths that have gradually enriched universal culture. Due to the variety and boundless questions the former point raises, this article will content itself with studying myth in poetry. It will, though, cast light on some of the prevailing functions of myth; more light will be thrown on the way Yeats employs myth, particularly Cuchulain myth, in his poems. Any related or subsidiary issues will be fertile ground for investigation.

\section{Myth's Multitudinous Functions}

A myth is an ancient story told to explain natural phenomena or delineate the genesis of a people. Hamilton (1982) elucidates that myth is an:

explanation of something in nature; how, for instance, any and everything in the universe came into existence: men, animals, this or that tree or flower, the sun, the moon, the stars, storms, eruptions, earthquakes, all that is and all that happens. (p. 19)

A substantial myth, accordingly, is the one that tries to answer man's questions. It is neither a sacred book nor a historical record, but an echo of ceaseless human endeavors to explain what surpasses the ordinary. This is why most myths are full of redoubtable creatures, amorphous beasts, deformed bodies, anomalous events, and wrathful gods and goddesses.

This omnipresence mirrors a fervent desire to know everything. The creation, for instance, has fed humans' imagination and propelled them to explore several punctilious methods for the sake of understanding. The result of such an ardent determination is the invention of narratives as diverse as those miscellaneous questions for the sake of unveiling the "natural, social, cultural, and biological facts" ("Myth and Mythology", 1985, p. 711). This is regardless of both space and time, for the primary function of a myth is an explanation. In this vein, John Milton (1608-1674) 
expounds: "First there was Chaos, the vast immeasurable abyss / Outrageous as a sea, dark, wasteful, wild" (as cited in Hamilton, 1982, p. 63). These lines show the Greek thoughts regarding the beginning of the world, the Creation. In the inception, there was nothing but "Chaos," silence, nothingness; then, the miracle took place. Aristophanes, the Greek poet, explains:

... Black-winged Night

Into the bosom of Erebus dark and deep

Laid a wind-born egg, and as the seasons rolled

Forth sprang Love, the longed-for, shining, with

wings of gold. (cited in Hamilton, 1982, p. 63)

Thanks to the birth of "Love," "Chaos" fell apart paving the way for light. Hesiod, the Greek poet, throws light on what came after. He expounds:

Earth, the beautiful, rose up,

Broad-bosomed, she that is the steadfast base

Of all things. And fair Earth first bore

The starry Heaven, equal to herself,

To cover her on all sides and to be

A home forever for the blessed gods. (cited in Hamilton, 1982, p. 64)

The myth here fulfils the function of explanation. The Hellenic myth in the preceding lines, as well as in other Roman, Norse, or Celtic narratives, revolves, most of the time, around explaining the origin of the world.

Once this puzzle is demystified, other interests take place and lay bare themselves to the outside world. The function, therefore, shifts enormously to play social and cultural roles embedded in reinforcing, strengthening and disseminating a culture's beliefs and customs.

Understanding the world and how it functions is therefore not everything, for myth offers certain ideologies hidden in a narrative form whose main function is to protect the self through defending the cultural characteristics of a certain community. In addition, the myth remains fraught with elements that can be shaped to meet infinite human needs. Here, myth presents itself as a way of thinking. Raffaele Pettazzoni, the historian of religion, presents mythical thinking to be "at once logical and illogical, rational and irrational, encompassing the totality of modes of human awareness ... myths arise from the human situation in a particular cultural-historical context" (cited in Long, 1983, pp. 702-703). Such a "situation," he explains, is all the time replete with "existential anxiety," which requires a sort of emotional or rather intellectual discharge manifested in the creation of myth. In order to cast more light on this issue, Pettazzoni distinguishes three levels of cultural development. The first phase covers the "hunting and gathering" stage; the second encompasses the "agricultural stage, which ushers in 'civilization'," while the third comprises "more complex forms of "agricultural stage" (cited in Long, 1983, p. 703). Each of the aforementioned stages owns a number of myths characterized by a set of dominant features of the 
era; that is to say, "animal myths in the first stage, fertility myths in the second, and savior myths in the third" (cited in Long, 1983, p. 703). This categorization shows that each stage has its own myths, whose functions and contents are inspired by the main worries of the inventors, or mythmakers, and tainted by their perspectives towards the outside world which is, in itself, affected by the overwhelming interests of the concerned era.

There are other functions whose degree of importance remains somewhat relative due to the absence of consensus on the value and role of myth. Despite this relativity, the common and preponderant one is this remarkable propensity to explain the rules that govern the existence of both humans and the world. This role is apparently central regardless of the type and stage of each myth. Yet, this necessitates studying the relation of myth to form. This relation will constitute the main topic of the second part of this article.

\section{Myth in/and Poetry}

A quick review of mythology reveals that almost each great literary work, basically the classics, is marked by a wide and rich presence of myth through interweaving plots and characters with mythical deities and paranormal events in spite of the genre of the work. However, poetry has also been the main medium noted by its profuse functions. In addition to its basic role as an artistic genre par excellence, poetry plays a critical role through putting a premium on both the function and value of myth.

Thus, how does poetry deal with myth and to what extent does it succeed in dealing with major myths that characterize a certain historical era? To shed more light on this issue, the present section will cover two eras. While the first part regards conventional poetry, the second one tackles modern poetry.

There is broad consensus about the close relationship between poetry and myth. The latter is used in poetry more than any other genre. Poetry, as Vincent Buckley (1983) points out, is the "most myth-saturated of all the artistic forms" (p. 259). This has always been the case be it in the past or in the present. Ancient Greeks, for instance, portrayed their most important concerns in poetry. When those concerns were dealt with or transmitted through sculpture or painting, "their outlook was still largely shaped by their poetical education and the principles which it implied" (Bowra, 1957, p. 177). Since myth reflected a colossal part of the Greek concerns, it was automatically and artistically incorporated in their poetry.

By the same token, it is thanks to Ovid, the Roman poet, that classical Latin myths have survived and inspired numerous generations afterwards. There are, certainly, other ancient writers and poets whose contributions are of great importance; yet, Ovid is comparatively the leader, if not the pioneer. Ovid wrote his tales during the reign of Augustus, the Roman Emperor, and it is noticeable that his tales are told at great length and that they cover nearly all the myths that existed and which might be reported by other poets or writers.

Arab World English Journal for Translation \& Literary Studies 
However, it is important to mention Ovid's own point of view regarding the myths he reported in his poetry. He wrote: "I prate of ancient poets' monstrous lies, / Ne'er seen or now or then by human eyes" (cited in Hamilton, 1982, p. 21). Yet, he tried to mollify his readers: "Never mind how silly they are. I will dress them up so prettily for you that you will like them" (cited in Hamilton, 1982, p. 21). His way of dressing those myths is very successful though he did not personally believe in what he reported. The same tales, however, represented mere reality for other ancient Greek poets, such as Hesiod and Pindar. The former claimed that the Muses told him: "We know how to tell falsehoods like the truth, and we know, when we choose, how to speak the truth" (Bowra, 1957, p. 145). It is, accordingly, a tough task to make a clear-cut demarcation between truth and reality when one deals with a subject as dubious as this. Despite the aforementioned, Ovid's contributions are of great value; the focal point remains the same notwithstanding the obvious ambiguity generated owing to the previous discordant views: poetry is a conspicuously efficient means to deal with the endless concerns that hinge on a myth.

In addition to Ovid, other ancient poets expressed the same concerns in their poetry, the most important of whom is undoubtedly Homer, who is particularly known by his eminent works The Iliad and The Odyssey. These works are replete with events related to Troy. In contrast with Ovid who did not believe in the stories he reported, Homer's position towards this subject remains unknown. Yet, the early Greeks believed that poetry should carry a certain element of truth (Bowra, 1957, p. 145).

Another great poet is Hesiod known particularly by his two poems "Works and Days" and "Theogony." Unlike the first poem which attempts to show human beings how to live a good life while enmeshed in the web of a rough world, the second one concerns mythology par excellence. This poem reflects Hesiod's questions about the creation of the world as well as the generation of the gods. It is, in other words, an early attempt to understand the nature of whatever surrounds the existence of human beings.

Pindar's position in ancient Greek poetry is also an interesting one. Pindar's odes are very famous; they were written during the splendid national festivals the Greeks organized in honor of the winners. The recurrent motif in those odes is a myth. Yet, what is noticeable about his poetry and his use of myth appertains to his diligent efforts to report no stories apart from those he believed in. If, for instance, a

story told that Apollo heard some news from a raven, Pindar corrected it; for he knew that Apollo, the lord of prophecy, needed no raven to tell him anything. He felt, indeed, that the old stories contained much that was false, and that is why he was never fully sympathetic to Homer. Of whom he says: 'On his falsehood [Homer's] and his winged cunning / A majesty lies. Art tricks and deceives us with tales. / And blind is the heart of the multitude of men. (Bowra, 1957, p. 145) 
Despite this comparatively acerbic remark, both Pindar and Homer are two foremost figures and major representatives of ancient Greek poetry whose basic feature is the use of myth regardless of its relative degree of credibility.

There are many other ancient Greek poets, like Aeschylus, Sophocles and Euripides; Latin as Apuleius who is the only writer who tells the famous story of Cupid and Psyche; and Roman like Catullus and Horace, both of whom incorporate myth in their poetry though in different ways. These poets, the aforementioned ones, and others deal with myth as any other component of the daily. What matters is not the credibility of a certain reported myth but, rather, the frequent presence of myth as a recurrent motif in ancient poetry, basically Greek poetry, as the present section has attempted to show. The foregoing facts display that the use of myth in ancient poetry tends to report facts said to have happened in a timeless past rather than to comment on or allude to them in a symbolic way. This statement gives birth to a new question which concerns the function of myth in modern poetry.

If the main feature that characterizes the use of myth in ancient poetry is most of the time mere reporting of old stories and events, recent poetic trends have altered their use of myth. Myth, for instance, is a motif in Milton's poems. Paradise Lost, as an example, is laden with numerous myths thanks to the poem's

rich deployment of classical mythology [which] comes dangerously close to the sort of embellishment where the familiar references require the stock response, although that response implies a highly civilized pleasure in the reference for its own sake, a form of connoisseurship. (Righter, 1957, p. 27)

For instance, John Milton's following verses are emblematic of this concern:

Nightly I visit: nor sometimes forget

Those other two equalled with me in fate,

So were I equalled with them in renown.

Blind Thamyris and blind Maeonides,

And Tiresias and Phineus, prophets old. (cited in Lerner, 1975, p. 84)

The poet employs classical mythology as he compares himself to "Thamyris", "Phineus", "Maeonides", and "Tiresias," the prophet believed to foretell the future. The presence of these names in this poem, unlike the erstwhile poets, aims at enriching, enforcing or exercising a certain impact, or a "sort of embellishment" as Righter explains.

Moreover, one can refer to Barthes who goes farther when he avows that any literary work will have its own mythical scope due to its presence as a form of speech. Quite similarly, Righter explains that it is used deliberately as a "means of depending and enriching a poem or narrative" (Righter, 1957, p. 28). A conspicuous example can be found in modern literature in general, for most writers use myth to enrich their works. Yeats, for example, as will be clarified in the next 
part of this article, profits a lot from the richness and variety of classical and Irish myths, all of which offer various dormant potentialities.

Another noticeable idea concerning the use of myth in modern poetry is the role of what may be termed "individualism." There are many uses of myth in modern poetry; yet, each poem incorporates myth individually. Each poet's inclusion of any myth is based upon the personal choice to rework the available elements so as to create a poem tainted by their own vision. The poems of both Eliot and Yeats are frequently marked by the presence of myth. Yet, one cannot say that these poets' choice is methodical in spite of the presence of a set of common traits. Righter (1957) elucidates:

First, whatever his purpose, point of view or whatever his historical source, for any writer his myth is inevitably chosen in response to the spiritual condition of modern man, to the very fact of existence in a post-mythological age. Second, it is a characteristic feature of such an age that no particular body of myth comes to hand naturally. (pp. 37-38)

That is to say, if Ovid, Pindar, and Hesiod use myth in their poems to satisfy the immature needs of the premature or the "primitive" man, modern poets do the same through their assiduous attempts to meet modern concerns of the modern man through inventing new and congruous methods. Modern poets, for example, reshape myths to go with the new era and satisfy the new worries of the modern man. The variety of such methods emerges from the richness and multitude of those queries and depends on the individual perspective of the poet. The next part of this paper will investigate the motives of a famous poet, Yeats, in order to contextualize the presence of myth in his poetry.

\section{Yeats, Poetry, and Myth}

Yeats is a prominent figure in the Irish literary scene. His prolific pen and dexterous mastery touches almost every literary field. Yet, the most important point is his fervent belief that art and literature should serve the national interests of the country they belong to. This explains the presence of such beliefs that are scattered throughout his writings including both plays and poems. Most remarkably, he even "urged Irish writers to use Irish landscape, to take themes from Irish legends and sagas, to saturate their work in whatever was local and therefore intimate" (Ellmann, 1983, p. 659).

Similarly, The Wandering of Oisin and Other Poems (1889), The Land of Heat's Desire (1894), and The Wind Among the Reeds (1894) constitute his collections of his early poems based on his knowledge of Irish national heritage and his charming interest in mysticism. The Celtic Twilight, published in 1893, comes to crown his knowledge and interest. Additionally, and like many other Irish poets, his works aim at resisting each agenda that tends to swallow Irish national characteristics. This gives birth to his "insistence on a new narrative for his people, his anger at England's schemes for Irish partition" (Said, 1994, p. 280). In his poem "Under Ben Bulben," Yeats calls:

Irish poets, learn your trade, 
Sing whatever is well made,

Scorn the sort now growing up

All out of shape from the toe to top,

Their unremembering hearts and heads

Base-born products of base beds. (cited in Abrams, 1993, p. 1896)

Obviously, Yeats follows suit. In "A Coat" his insistence and reliance on the presence of myth are conspicuous and direct: "I made my song a coat / Covered with embroideries / out of old mythologies" (cited in Abrams, 1993, p. 1896). His determination to benefit from the rich inherited local stock of folktales, legends and myths aims at creating a "coherent myth and indirectly a national continuity of feeling, a sense of national identity in depth" (Righter, 1957, p. 30). In "An Irish Literature", Yeats affirms that the fountainhead of this determination is his belief in his foremost task to play an efficient role in enriching the "national literature" that would make "Ireland beautiful in the memory" (cited in Abrams, 1993, p. 1900).

Consequently, "The Madness of King Goll," whose original title is "An Irish Legend," and as the title shows, is based upon a local legend which reports the story of the madness of an old Irish king who hid himself in a valley in Cork like all other Irish madmen. The same thing applies to "Who Goes with Fergus?" which deals with the Irish king Fergus who voluntarily gave up his throne to Conchubar. "The Wild Swans at Coole" makes direct reference to Baile and Aillin; the myth says that both of them changed to swans. The same theme is found in an earlier poem, "Baile and Aillinn," published in 1903.

Additionally, various mythical figures, either Roman or Greek, are widely scattered in his other poems. For instance, Venus, the Roman goddess of love and beauty, is referred to in "A Prayer for My Daughter" as "that great Queen, that rose out of the spray" (Cited in Abrams, 1993, p. 1882). His poem "Leda and the Swan" published in 1923 goes back to the Greek myth and to Zeus whose visit to Leda resulted in the birth of both Helen and Clytemnestra -in another version of Helen and Pollux (Hamilton, 1982, p. 41). The outcome of this birth is annihilation. In the same poem, "Leda and the Swan," Yeats writes: "A shudder in the loins engenders there / The broken wall, the burning roof and tower / And Agamemnon dead" (cited in Abrams, 1993, p. 1884). Helen is also referred to, though indirectly, in his poem "Among School Children" where the poet dreams of "a Leaden body" (cited in Abrams, 1993, p. 1885). She is also mentioned in "Long-Legged Fly" published in 1937.

As this section has tried to show, Yeats refers to various myths including Greek, Roman and Irish, all of which are beautifully interwoven with his verses. Yet, one of his most eminent and most myth-saturated poems is undoubtedly "The Second Coming." This work, which shows the poet's position towards the "falling apart" of civilization, interweaves the Biblical myth with the Greek one.

As far as the first myth is concerned, Yeats uses many chapters of the Bible such as Revelation and Matthew 24; he uses "twice ... the standard locution for announcing the vision of the day of 
horror, is 'at hand,' to start the visionary second stanza" (Purdy, 1994, p. 75). The presence of the locution "is at hand" twice in the poem converges with the Biblical myth as it reminds the reader of the Bible which uses the same phrase twenty times.

In the same poem, Yeats also presents an emotive image of a "shape with lion body and the head of a man" (cited in Abrams, 1993, p. 1881). This horrific presentation is reminiscent of both Biblical and Greek myths. The first one refers to Ezekiel's story in the Bible which mentions a daemonic creature that owns "four different faces: a human face in front, a lion's face at the right, a bull's face at the left, and an eagle's face at the back" (Good News Bible, 1979, p. 799). The same image appears in Daniel's book when Daniel dreams of:

Four huge beasts came up out of the ocean, each one different from the others. The first one looked like a lion, but had wings like an eagle ... the second beast looked like a bear standing on its hind legs. It was holding three ribs between its teeth ... [The third] looked like a leopard, but on its back there were four wings, the wings of a bird, and it had four heads ... [The fourth] was powerful, horrible, terrifying. With its huge iron teeth it crushed its victims, and then it trampled on them. Unlike the other beasts, it had ten horns ... (Good News Bible, 1979, p. 862)

Like the poet's "sight" which is troubled by the appearance of the deformed creature, Daniel is taken aback by these creatures that loom unexpectedly from the ocean.

The second source from which Yeats derives the image of the beast is the Greek myth presented in Oedipus the King written by Sophocles. This monstrous creature, the Sphinx, is the "daughter of Echidna and Orthus or Typhon," it owns wings, a woman's head, and a lion's body (Mercantante, 1988, p. 597). It is also called Cherubim, "the Hebrew plural of "cherub" (Browning, 1996, p. 391). The latter "occurs 91 times in the Hebrew Bible. It denotes the Israelite counterpart of the Sphinx known from the pictorial art of the ancient Near East" (Toorn, Becking, \& Host, 1995, p. 362). According to this myth, the mission of the Sphinx was to destroy Thebans because of their inability to solve her inscrutable conundrums which propelled most people to remain inside Thebes. Her riddle was: "What creature ... goes on four feet in the morning, on two at noonday, on three in the evening?" (Hamilton, 1982, p. 257). This riddle stood as the fountainhead of death, but Oedipus, being quite a wise man, defeated her. "Man," he said. "In childhood he creeps on hands and feet; in the manhood he walks erect; in old age he helps himself with a staff" (Hamilton, 1982, p. 25). This poem, like many others, shows his "interest in mystic religion and the supernatural," both of which serve him enormously since they simplify his task thanks to the limitless symbolic richness each source offers (Drabble, 1995, p. 1104). The effect of the use of both Biblical and Greek myths is commensurate with that of another national myth, the Cuchulain. The way Yeats deals with this myth in his poetry and its dimensions compose the main concern of the last part of this article. 


\section{Yeats and the Cuchulain Myth}

Cuchulain is one of the main heroes in Irish mythology. Yeats employs this figure quite frequently in most of his works, including both poems and plays. The former category contains "The Death of the Cuchulain," (1892) which was rewritten as "Cuchulain's Fight with the Sea" (1915), and "Cuchulain Comforted" (1939) whose original title is "The Death of the Cuchulain." The latter, which refers to the second category, includes On Baile's Strand (1903), The Goldon Helmet (1908), At the Hawk's Well (1916) and The Only Jealousy of Emer (1919). The poet's use of the Cuchulain myth in these works shows his endeavors to profit from the empowering capacities national heroic characters offer.

The Cuchulain myth revolves around Cuchulain, one of the main heroes of Ulster cycle in Irish mythology. Cuchulain, as he appears in this cycle, is the "son of Dechtire, sister of King Conchobar of Ulster, and the son god Lug" ("Cu Chulain", 1983, p. 308). His beauty and strength are described as incomparable. His real name is Setanta whereas Cuchulain ("watchdog of Cullan") was given to him as a result of his bravery which enabled him to kill a savage watchdog and take care of guarding the house and the kingdom in its place ("Cu Chulain", 1983, p. 308). During the Cattle Raid of Cooley (Tain Bo Cualnge), Maeve, Queen Medb of Connaught, made an effort to steal the supernatural brown bull of Ulster. Cuchulain, however, stood by his countrymen, resisted the attack alone thanks to his immunity to the magic spell which engulfed the entire country and rendered the Irish no more than prisoners of their debility ("Cu Chulain", 1983, p. 308). This brave and glorious image characterizes Cuchulain's presence in each work which deals with this outstanding hero, be it prose or poetry.

Cuchulain, the champion of Ulster, appears in many stories and versions all of which are fraught with deeds and signs of incontrovertible gallantry reminiscent of classical myths. Yeats, by the same token, devotes a number of his poems to this Irish hero. In "The Secret Rose," the main concern of Yeats is the idea of beauty embedded in and symbolized by the "Rose." In this poem, like in "The Rose of the World," Yeats talks more precisely about the platonic idea of beauty. Beauty, he writes, is a "secret rose," an "inviolate" one; it is something which people seek everywhere in "the Holy Sepulchre," in the "wine-vat," and "among pale eyelids"; its "leaves enfold" everyone, ranging from the "ancient beards," "king Conchubar" to Cuchulain who "met Fand walking among flaming dew / By a grey shore where the wind never blew, / And lost the world and Emer for a kiss" (cited in Abrams, 1993, p. 1870). Cuchulain's presence in this poem is entirely symbolic. Its weight is nearly equal to that of Conchubar. Yet, the presence of both characters is quite significant. Yeats deals here with a neoplatonic idea and yet he makes use of the Irish heritage to remind the reader of the Irish heroes: Conchubar, Cuchulain, and Caoilte who "drove the gods out of their liss" (cited in Abrams, 1993, p. 1870). The same hero, Cuchulain, fulfills the same symbolic function in his poem "The Circuss Animals' Desertion." Yeats writes: "And when the Fool and Blind Man stole the bread / Cuchulain fought the ungovernable sea" (cited in Abrams, 1993, p. 1894). Thus is Cuchulain, brave, shining, and ready to stand in front of each threatening danger.

Arab World English Journal for Translation \& Literary Studies 
Rafroidi clarifies that Cuchulain is a "rediscovery of the Romantic period," found particularly in Charlotte Brooke's Reliques (1983, p. 137). The latter contains rich references to "Conloch" or "the Lamentation of the Cucullin over the body of his son Conloch" (Rafroidi, 1983, p. 137). Though some writers, especially poets, concentrate more on the sentimental sides of such heroes and avoid, either intentionally or unintentionally, the other sides particularly the tragic one, other poets, such as Austin Clarke, do not:

Terrible within the West!

Flaming among those kingdomless sea-mountains, And bound by storm against the stupendous cliffs, Forth sprang Love, the longed-for, shining, with Cuchullin shone! (cited in Rafroidi, 1983, p. 137)

Rafroidi (1983) elucidates that great mythical names, and down to John Millington Synge, are female such as Roisin Dubh, Kathleen niHoulihan, and Deirdre of the Sorrows. Thus, for "Cuchulain to come to his own again required a wider and more profound knowledge and a popularization of his high deeds, together with an adequation of his destiny to the tendencies, experiences and needs of a different generation" (p. 138).

The Cuchulain poems of Yeats, especially "Cuchulain's Fight with the Sea," fall under this category. This poem interweaves "knowledge," which Yeats finds in Standish James O'Grady's History of Ireland, with "popularization" demonstrated in the main objective of writing this particular poem. The poem describes the heroic deeds of Cuchulain redolent of the poet's belief in his primary task to make the old Irish heroes alive again, heroes such as Fion and Oisin.

Such endeavors to rediscover Irish heroes aimed at giving a push to the literary movement in an era of intense turmoil manifested in the provoking position the British Empire took towards Ireland. The success of the literary movement, fomented by the rediscovery and, henceforth, the "popularization" of the Cuchulain myth is what Ireland needed then. Like the Siegfried myth which met Germany's ardent thirst for a hero to face the French, the rediscovery of the Cuchulain myth was received with feelings of great approval and splendid comfort, for its representation restored the Irish national dignity. For example, George Russell's reaction to such a noteworthy rediscovery is an interesting one since he compares this rebirth with a man "who suddenly feels ancient memories rushing at him, and knows he was born in a royal house, that he had mixed with the mighty of heaven and earth and had the very noblest companions" (Rafroidi, 1983, p. 139).

The difference, however, lies in reception itself. Rafroidi (1983) states:

Thus did Yeats reinvent Cuchulain not only for self-expression but also as the ritual of lost faith, in the hope of re-creating a heroic age for Ireland and resuscitating an all-round, Parnell-like chief: 'warrior, aristocrat, political leader and visionary'. (p. 142).

Arab World English Journal for Translation \& Literary Studies 
As a poet, one of the major tasks of Yeats is to contrive to nurture those diligent efforts whose target is to promote the representative and symbolic functions of the rediscovered myth as an initial step towards "re-creating" a comparatively similar era. Then would come the role of the politician, the nationalist, the rebel, and why not the layman? The sole discrepancy resides here. For example, Patrick Pearse, a schoolmaster, a poet, and a leader in the movement which attempted to restore the Gaelic language in Ireland, showed a different stand. Pearse "finally identifies himself with the hero in action instead of merely indulging a nostalgic mood, thus transmuting myth into an active, present force; before being 'changed, changed utterly' through martyrdom" (Rafroidi, 1983, p. 142). This comparatively unforeseen "martyrdom" was literally instigated by his daring “identification" with Ulster's champion. The latter's overwhelming and empowering inspiration changed Pearse's prosperous life totally devoted to fight British hegemony. Actually, it put an end to it in 1916.

In fact, Easter Monday of 1916 is a memorable day in Irish history, for it witnessed the start of a new phase of Irish national struggle against the British government. The latter was taken aback by an audacious insurrection launched by Irish nationalists. The revolt, though supported by Germany, proved to be mere fiasco and culminated in the execution of a number of mutinous nationalists such as Thomas MacDonagh and Major John MacBride in addition to the leaders of the rebellion, Patrick Pearse and James Connolly. The impact of such a bloody execution was saliently tremendous on Yeats, for it "moved him deeply after an initial shock of horror, when he thought it had destroyed his own life's work" (Lyons, 1983, p. 217). Such agony, increased by his personal acquaintance with the main executed rebels, gave birth to his remarkable poem "Easter 1916." The latter mirrors, in a pitiful and detailed way, the whole scene starting from the incipient stages of the ambitious and courageous rising to the bloody aftermath shown in the ferocity of the intolerable execution of the freedom-seeking men.

Thus is the effect of the regeneration of the Cuchulain myth. It has always been the same. Cultural components, including myths, legends, folktales, rituals, beliefs and customs, compose most of the time the fountainhead of any heroic indulgence in the national interests of one's own country. They do not only move and enhance a nation's collective consciousness but, most importantly, they push it to take a positive stand.

The foregone has attempted to shed light on the functions and reception of Cuchulain myth, whose rediscovery in the beginning of the nineteenth century has redirected the intention of the concerned parties to the affluent aspects of a once influential, shining and inspiring heroic star. This reappearance in Ireland was necessary, if not mandatory, in a turbulent age whose main characteristic was political chaos engendered by a seemingly insidious imperial hegemony governed, indeed, by greedy and bigoted mentalities and policies. This chaotic disorder, lumping together freedom seekers and trouble makers and arrogantly repudiating to see the clear-cut discrepancy between them, paved the way for an effective presence of this myth, nourished the great and endless expectations of liberty worshippers, accentuated their fierce fight against freedom antagonists and led them, ultimately, to sacrifice their lives as a result of their axiomatic contravention.

Arab World English Journal for Translation \& Literary Studies 


\title{
Conclusion
}

Nowadays, thrown in a topsy-turvy era noted by its bloody fatuous fights that make humanity on the verge of utter anarchy, new questions loom large to everyone since the turmoil that gives birth to those queries is no longer esoteric. Each worried member of society, especially the poet, is aware that there are few opportunities in front of human beings in an increasingly demythologized age. Within such circumstances, what can the revival of any myth, be it Greek, Roman, Irish, or Indian, represent? Each myth, no matter how preposterous it might seem, is indeed replete with empowering capacities that can fuel the daunted, the despaired and the difficult as the case with Patrick Pearse whose identification with the Irish hero pushed him to sacrifice his life for the sake of the inalienable prerogatives of his country. Such a wonderful national accomplishment, as it is reported in one of the best poems of Yeats, "Easter 1916," is just an example since, historically speaking, there are many other cases.

Therefore, the current era necessitates the revival of the traditional interest in the study of cultural and national representatives, some of whom, if not the majority, are found in the rich stock of myths of each nation. This resuscitating, or awakening, if accompanied by the necessary means and carried by the appropriate capacities, will be sufficient as it will positively affect the dormant potentialities who will voluntarily take part in disseminating and enriching the multi-dimensional roles of those cultural and national myth-saturated representatives ripe for fulfilling the same functions as they have done all over the years. As a poet, whose borrowed references are frequently mythical, Yeats believes in a second chance, may be in his own Godot. He says: "Surely some revelation is at hand; / Surely the Second Coming is at hand" (cited in Abrams, 1993, p. 1896). Is it really "at hand"?

\begin{abstract}
About the Author:
Fatima Zahra Touzani has been teaching English at the Faculty of Letters and Human Sciences, Cadi Ayyad University in Marrakech, Morocco, since 2003. She is currently preparing a PhD dissertation in postcolonial studies. Her major research areas are: postcolonial studies, modern poetry, and modern fiction. ORCID: https://orcid.org/0000-0001-9385-2701
\end{abstract}

\section{References}

Abrams, M. H., ed (1993). The Norton Anthology of English Literature. 2. $6^{\text {th }}$ ed. London: Norton.

Bowra, C. M. (1957). The Greek Experience. New York: Mentor Books.

Browning, W. R. F. (1996). A Dictionary of the Bible. Oxford: Oxford University Press.

Buckley, V. (1983). Poetry and the Avoidance of Nationalism. In O. Macdonagh, W. F. Mandle, \& P. Travers (eds.), Irish Culture and Nationalism (pp. 258-279). London: Oliver MacDonagh.

Cu Chulain (1983). Encyclopaedia Americana. 8. Danbury: Grolier Incorporated.

Drabble, M., ed (1995). The Oxford Companion to English Literature. Oxford: Oxford University Press.

Ellmann, R. (1983). Yeats, William Butler. Encyclopaedia Americana. 29. Danbury:

Arab World English Journal for Translation \& Literary Studies 
AWEJ for Translation \& Literary Studies Volume, 3 Number 1. February 2019

The Cuchulain Myth in the Poetry of W. B. Yeats

Touzani

Grolier Incorporated.

Good News Bible (1979). New York: American Bible Society.

Hamilton, E. (1982). Mythology. New York: A Mentor Book.

Lerner, L. (1975). An Introduction to English Poetry. London: Edward Arnold Ltd.

Long, C. H. (1983). Mythology. Encyclopaedia Americana. 19. Danbury: Grolier Incorporated.

Lyons, F. S. L. (1983). Yeats and the Anglo-Irish Twilight. In O. Macdonagh, W. F. Mandle, \&

P. Travers (eds.), Irish Culture and Nationalism (pp. 212-238). London: Oliver MacDonagh.

Mercantante, A. S. (1988). The Facts on File Encyclopaedia of World Mythology and Legend. New York: Facts on File.

Myth and Mythology (1985). The New Encyclopedia Britannica. 24. Chicago: Encyclopedia Britannica, Inc.

Purdy, D. H. (1994). Biblical Echo and Allusion in the Poetry of W. B. Yeats. London: Associated University Press.

Rafroidi, P. (1983). Imagination and Revolution: The Cuchulain Myth. In O. Macdonagh, W. F. Mandle, \& P. Travers (eds.), Irish Culture and Nationalism (pp. 137-148). London:

Oliver MacDonagh.

Righter, W. (1957). Myth and Literature. London: Routledge.

Said, E. W. (1994). Culture and Imperialism. London: Vintage.

Toorn, K. V. D., Becking B., \& Host, P. W. V. D., eds (1995). Dictionary of Deities and Demons in the Bible. Leiden: E. J. Drill.

Arab World English Journal for Translation \& Literary Studies

ISSN: 2550-1542 | www.awej-tls.org 